$4^{\text {th }}$ International Meeting on Calcitonin Gene-Related Peptide (CGRP)

TheScientificWorld (2001) 1(S1), 33

ISSN 1532-2246; DOI 10.1100/tsw.2001.416

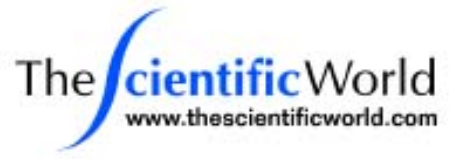

\title{
A NOVEL NONPEPTIDE CGRP RECEPTOR ANTAGONIST, 'COMPOUND 1' (WO98/11128) IS A HIGH AFFINITY COMPETITIVE ANTAGONIST AT THE CGRP RECEPTOR IN HUMAN CORONARY ARTERIES
}

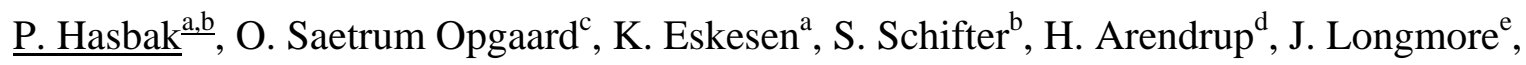 \\ and L. Edvinsson ${ }^{\mathrm{a}}$
}

a Department of Clinical Experimental Research, University Hospital of Copenhagen, Glostrup,

Denmark; ${ }^{b}$ Department of Clinical Physiology and Nuclear Medicine, University Hospital of Copenhagen, Glostrup, Denmark; ' Department of Pharmacology, College of Medicine, University of California at Irvine, Irvine, CA; ${ }^{\mathrm{d}}$ Department of Thoracic Surgery, Rigshospitalet, Copenhagen,

Denmark; ${ }^{\mathrm{e}}$ Merck Sharp \& Dohme, Neuroscience Research Centre, Harlow, Essex, U.K.

Functional CGRP and adrenomedullin receptors appear to consist of at least three different kinds of proteins: the calcitonin receptor-like receptor (CRLR), receptor-activity-modifying protein (RAMPs), and the receptor component protein (RCP) that couples the receptor to the cellular signal transduction pathway.

Using reverse transcriptase - polymerase chain reaction the presence of mRNA sequences encoding CRLR, RCP, and the three types of human RAMP that have been cloned were demonstrated in human left anterior descending (LAD) coronary arteries.

Relaxant responses were studied on isolated segments of LAD after precontraction with U46619 $\left(10^{-7} \mathrm{M}\right)$. The human peptides $\alpha \mathrm{CGRP}$, AM, and amylin induced relaxation with $\mathrm{pEC}_{50}$ values of $8.2 \pm 0.2,6.9 \pm 0.1$, and $6.3 \pm 0.2 \mathrm{M}$ (mean \pm S.E.M.), respectively.

The antagonistic properties of a novel nonpeptide CGRP antagonist 'Compound 1' (WO98/11128) were compared to the well-known $\mathrm{CGRP}_{1}$ receptor antagonist $\alpha \mathrm{CGRP}_{8-37}$. Preincubation with $\alpha \mathrm{CGRP}_{8-37}\left(10^{-7}\right.$ to $\left.10^{-5} \mathrm{M}\right)$ and 'Compound 1 ' $\left(10^{-7}\right.$ to $\left.10^{-5} \mathrm{M}\right)$ caused a dosedependent rightward shift of the concentration-response curves for $\alpha \mathrm{CGRP}$. The $\mathrm{pA}_{2}$ values were 7.3 and 7.0,respectively.

Preincubation with $\alpha \mathrm{CGRP}_{8-37}\left(10^{-6} \mathrm{M}\right)$ and 'Compound 1 ' $\left(10^{-6} \mathrm{M}\right)$ caused significant rightward shift of the concentration-response curves for AM and amylin. Preincubation with $\mathrm{AM}_{22-52}\left(10^{-6} \mathrm{M}\right)$ had no significant antagonistic effect.

In conclusion, mRNA for the components forming CGRP and AM receptors were present in the human LAD. $\alpha \mathrm{CGRP}, \mathrm{AM}$, and amylin mediated vasorelaxation via the $\mathrm{CGRP}_{1}$ receptor. Compound 1 acted as a selective nonpeptide antagonist at the CGRP receptor and could thus become a tool for the study of CGRP-mediated functional responses in human tissue. 


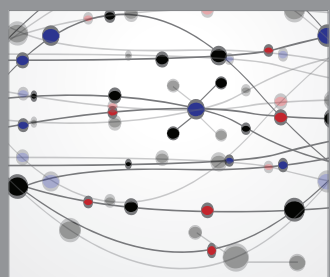

The Scientific World Journal
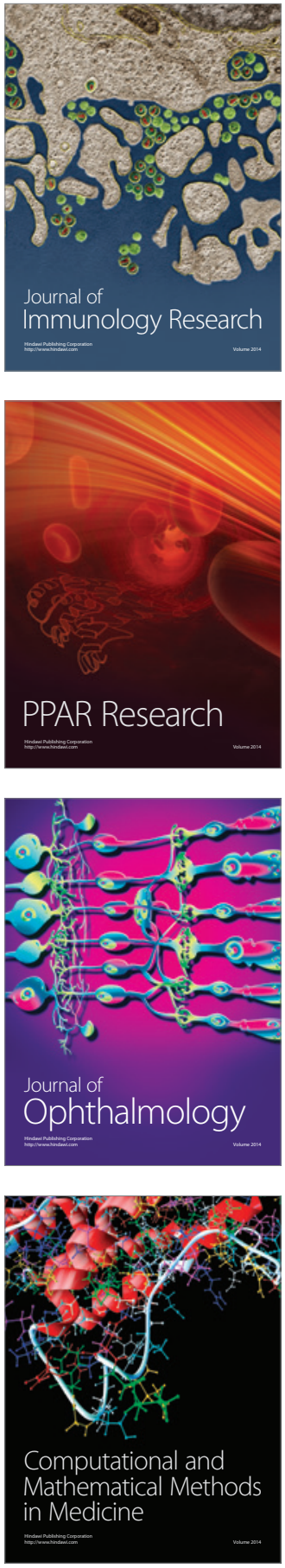

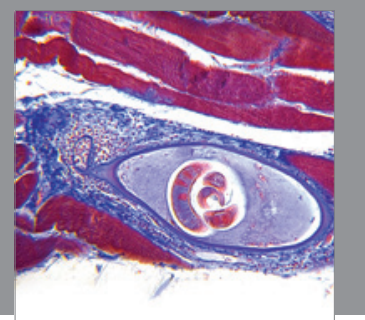

Gastroenterology

Research and Practice
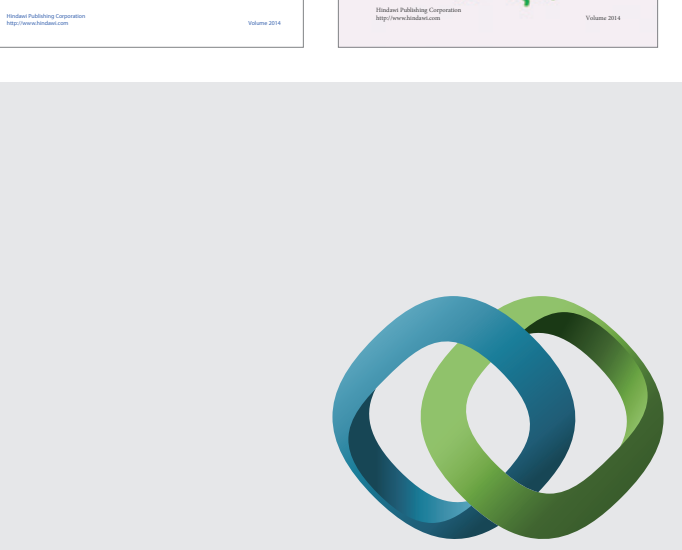

\section{Hindawi}

Submit your manuscripts at

http://www.hindawi.com
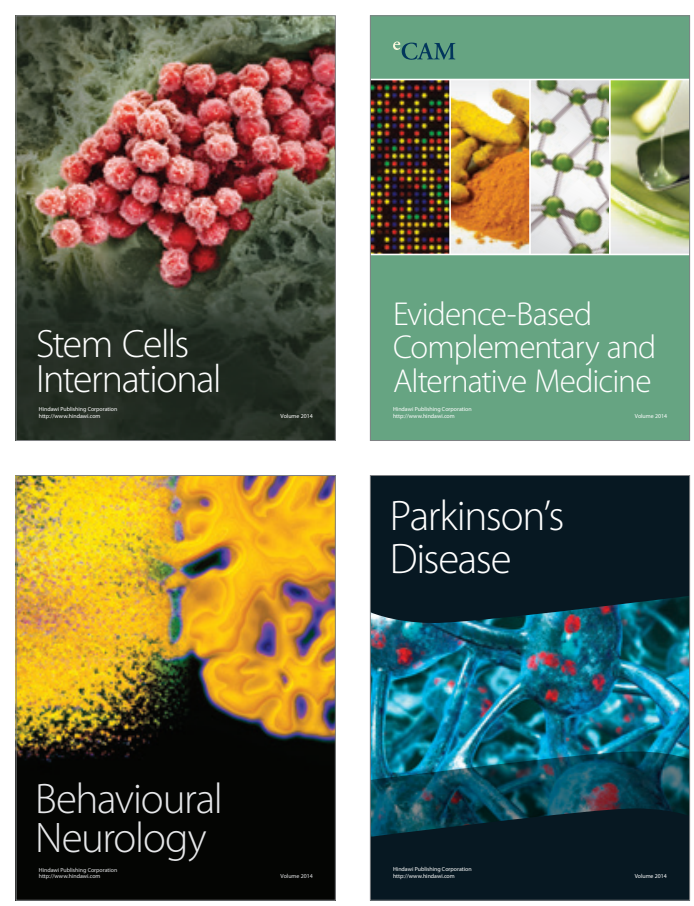

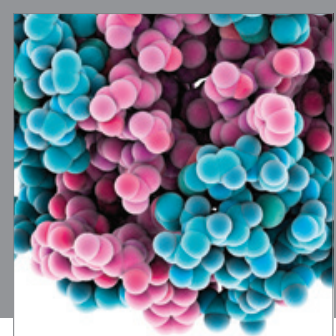

Journal of
Diabetes Research

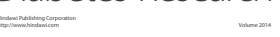

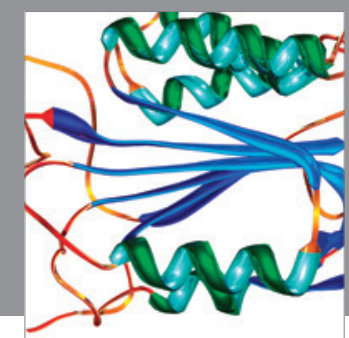

Disease Markers
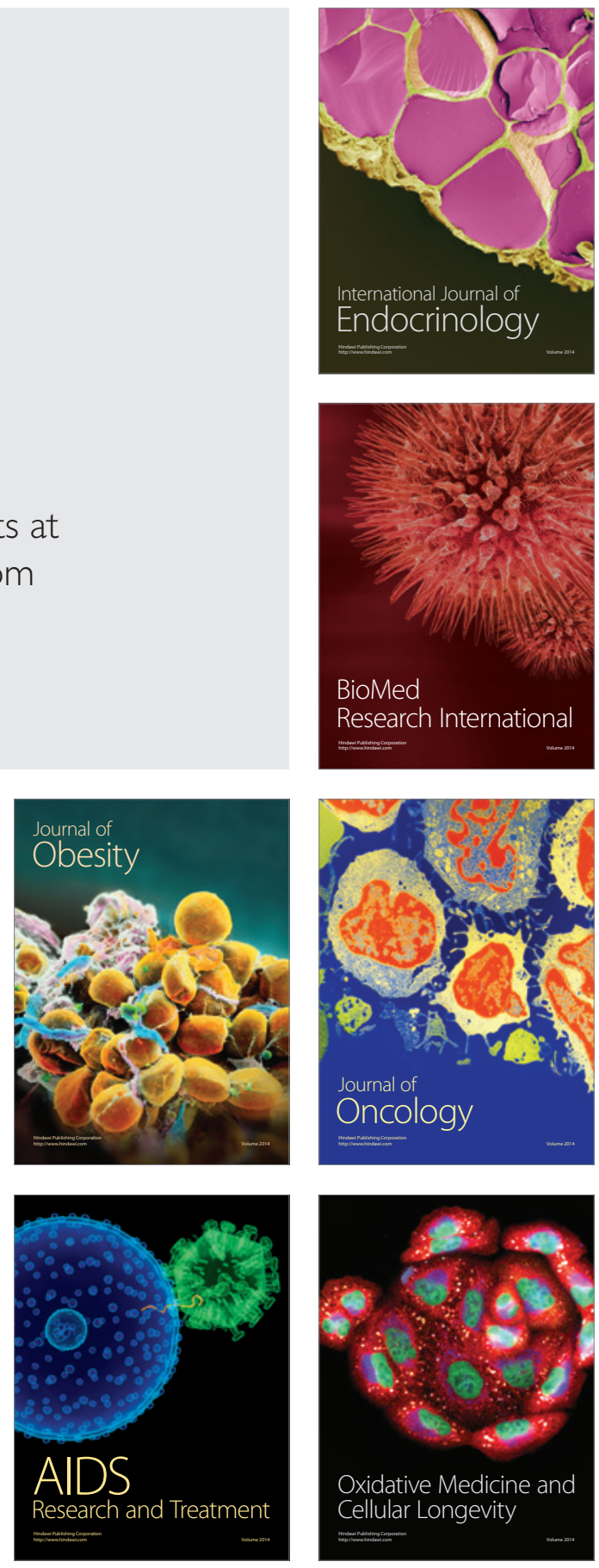